\title{
Edukasi Kesehatan Reproduksi Wanita pada Pengajian Aisyiyah Turisari, Desa Palur Kulon, Kecamatan Mojolaban, Kabupaten Sukoharjo
}

\author{
Ropitasari $^{1 *}$, Rachmi Fauziyah Rahayu² dan Retno Tri Astuti Ramadhana ${ }^{1}$ \\ ${ }^{1}$ Program Studi D3 Kebidanan, Sekolah Vokasi, Universitas Sebelas Maret, Surakarta, Indonesia; ${ }^{2}$ Bagian \\ Radiologi RSUD Dr. Moewardi, Surakarta, Indonesia
}

Diterima: 10 Agustus 2020; Disetujui: 21 Oktober 2020

\begin{abstract}
Abstrak
Pengetahuan kesehatan reproduksi bukan saja penting dimiliki oleh bidan atau dokter, tetapi sangat penting pula dimiliki khususnya oleh setiap wanita sebagai remaja putri maupun seorang istri ataupun sebagai ibu atau calon ibu dari anak-anaknya demi kesehatan agar tercapai kesejahteraan wanita. Kesehatan reproduksi merupakan suatu kondisi sehat pada semua sistem organ, fungsi dan proses reproduksi. Tujuan pengabdian edukasi kesehatan reproduksi wanita ini adalah memberi pengetahuan agar berperilaku benar yang akurat mengenai kesehatan reproduksi masing-masing wanita. Metode pelaksanaan kegiatan ini melalui penyuluhan edukasi oleh tim dosen D3 Kebidanan sebagai paramedis dan dokter bagian radiologi sebagai tim medis, maupun mahasiswa kebidanan, dengan materi tertulis maupun video aplikatif. Hasil kegiatan diikuti 105 wanita yang tergabung dalam kegiatan pengajian rutin ibu-ibu, 50 wanita di usia produktif terbagi menjadi 40 orang usia reproduksi, 4 orang usia remaja awal, 6 orang usia remaja akhir, serta 55 wanita berusia lanjut usia. Hasil evaluasi dengan memberikan kuesioner setelah kegiatan, 60 orang wanita mempunyai pengetahuan baik, 25 orang berpengetahuan sedang dan 15 wanita mempunyai pengetahuan buruk mengenai kesehatan reproduksi wanita, sisanya tidak mengisi kuesioner karena faktor usia, yaitu 5 wanita berusia di atas 70 tahun. Kesimpulan, masih ada beberapa wanita yang belum paham mengenai menjaga kesehatan reproduksinya sehingga kegiatan edukasi ini perlu dilakukan secara periodik.
\end{abstract}

Kata kunci: edukasi; kesehatan reproduksi; wanita

\section{Women's Reproductive Health Education in Aisyiyah Resitation Turisari, Village of Palur Kulon, Mojolaban Sub-District, Sukoharjo Regency}

\begin{abstract}
Knowledge of reproductive health is not only important for a midwife or general practitioners to have, but it is also very important for every woman as a young woman or a wife or as a mother or prospective mother of her children for the sake of health in order to achieve women's welfare. Reproductive health is a healthy condition in all organ systems, functions and reproductive processes. The aim of this service to educate on women's reproductive health is to provide knowledge in order to behave correctly and accurately regarding the reproductive health of each woman. The method of implementing this activity is through educational outreach by a team of D3 Midwifery lecturers, as paramedics and doctors as a medical team, as well and midwifery students, with written materials and applicative videos. The results of the activity were followed by 105 women who are part of
\end{abstract}

* Corresponding author: ropita.3179@staff.uns.ac.id

Cite this as: Ropitasari, Rahayu, R. F., \& Ramadhana, R. T. A. (2020). Edukasi Kesehatan Reproduksi Wanita pada Pengajian Aisyiyah Turisari, Desa Palur Kulon, Kecamatan Mojolaban, Kabupaten Sukoharjo. AgriHealth: Journal of Agri-food, Nutrition and Public Health, 1(2), 110-116. doi: http://dx.doi.org/10.20961/agrihealth. v1i2.43622 
the routine recitation activities of mothers, 50 women of productive age divided into 40 reproductive ages, 4 early adolescents, 6 late adolescents, and also 55 elderly women. Questionnaires were given after the activity, 60 women had good knowledge, 25 women had moderate knowledge and 15 women had poor knowledge about women's reproductive health, the rest did not fill out the questionnaire because of the 5 women over 70 years old. In conclusion, there are still some women who do not understand about maintaining their reproductive health, so this educational activity needs to be carried out periodically.

Keywords: education; reproductive health; women's

\section{PENDAHULUAN}

Sehat merupakan suatu keadaan kesehatan yang sempurna baik secara fisik, mental dan sosial dan bukan semata-mata terbebas dari penyakit atau kecacatan. Definisi kesehatan reproduksi menurut hasil ICPD (International Conference for Population and Development) 1994 di Kairo adalah keadaan sempurna fisik, mental dan sosial yang utuh kesejahteraan sosial dan tidak semata-mata ketiadaan penyakit atau kelemahan bebas dari penyakit atau kecacatan, dalam segala hal yang berkaitan dengan sistem reproduksi dan fungsi serta prosesnya (Direktorat Kesehatan Keluarga Kemenkes RI, 2017).

Keseriusan pemerintah dalam memberi perhatian akan penanganan permasalahan kesehatan reproduksi, termasuk sehat secara psikis maupun mental. Hal ini dituangkan dalam kebijakan Peraturan Pemerintah Nomor 61 tahun 2014 tentang Kesehatan Reproduksi, mengenai jaminan pemenuhan hak kesehatan reproduksi bagi setiap orang dan menjamin kesehatan ibu dalam usia reproduksi agar melahirkan generasi yang sehat dan berkualitas, serta mengurangi Angka Kematian Ibu (AKI). Selain itu, pemerintah juga menjamin kesehatan ibu, mengurangi angka kesakitan, AKI dan bayi baru lahir, menjamin tercapainya kualitas hidup dan pemenuhan hak-hak reproduksi dan mempertahankan dan meningkatkan kualitas pelayanan kesehatan ibu dan bayi baru lahir yang bermutu, aman dan bermanfaat sesuai dengan perkembangan ilmu pengetahuan dan teknologi (Peraturan Pemerintah, 2014).

Sehat secara psikis dan mental didefinisikan sebagai kondisi yang memungkinkan individu memahami potensi-potensinya yang mencakup tiga komponen yaitu pikiran, emosional dan spiritual. Sehat pikiran tercermin dalam berbagai cara berfikir atau jalan fikir. Sehat emosional tercermin dari bagaimana cara seseorang dalam mengekspresikan berbagai kondisi seperti sedih, bahagia, senang dan lain-lain. Sehat spiritual tercermin dalam ekspresi keagamaan yang diekspresikan melalui ungkapan syukur, kepercayaan, pujian terhadap Sang Pencipta melalui ibadah. Sehat secara sosial berarti terwujudnya interaksi setiap individu dengan sesama tanpa membedakan perbedaan suku, ras, maupun warna kulit, sehingga tercipta rasa toleransi dan persatuan. Sehat secara kultural berarti terwujudnya kehidupan yang memiliki peradaban setiap individu dengan perbedaan suku, ras, maupun warna kulit, sehingga tercipta rasa toleransi dan persatuan.

Berdasarkan data Pemerintah Kabupaten Sukoharjo, didapatkan jumlah penduduk Desa Mojolaban total sebanyak 906.403 jiwa, 453.879 jiwa laki-laki, 452.524 jiwa wanita. Jumlah penduduk wanita sekitar 49,9\% jiwa, 126.024 jiwa terdiri dari wanita berumur 25-34 tahun dalam rentang usia reproduksi sehat (Pemkab Sukoharjo, 2018). Data mengenai kesehatan reproduksi wanita di Sukoharjo menyebutkan bahwa sasaran pada pemeriksaan SADANIS (Pemeriksaan Payudara Klinis) dan pemeriksaan tes IVA (Inspeksi Visual Asam Asetat) pada wanita usia 30-50 tahun sebanyak 139.330. Capaian pemeriksaan leher rahim dan payudara 3.675 orang $(2,64 \%)$. Data mengenai tes IVA positif sebanyak 890 orang $(24,22 \%)$. Kasus dengan tumor/benjolan 38 orang $(1,03 \%)$. Capaian pelayanan IVA masih sangat rendah karena masih rendahnya kesadaran untuk melaksanakan deteksi dini kanker leher rahim maupun kanker payudara.

Berdasarkan beberapa ulasan di atas dapat disimpulkan bahwa sangat penting memberi informasi kepada para wanita untuk selalu menjaga kondisi kesehatan reproduksinya, mulai dari anak-anak, remaja, dewasa, istri maupun ibu sampai kondisi perempuan tersebut memasuki masa menopause. Pendidikan kesehatan ini 
mempunyai tujuan agar wanita mau berperilaku hidup sehat, khususnya dalam menjaga organ reproduksinya sehingga tidak timbul masalah di salah satu organ reproduksinya. Rencana tindak lanjut dari kegiatan edukasi ini ialah para ibu diminta mengisi kuesioner mengenai perilaku yang benar dalam menjaga organ reproduksi wanita. Selanjutnya, para wanita diminta menirukan gerakan Pemeriksaan Payudara Sendiri (SADARI), cara membersihkan organ genetalia yang benar dan agar para ibu yang telah menikah tidak takut atau tidak malu melakukan pemeriksaan tes IVA di Puskesmas, untuk mengetahui kesehatan jalan lahirnya.

\section{BAHAN DAN METODE}

Bahan edukasi kegiatan ini berupa materi presentasi slide PowerPoint maupun video aplikatif mengenai SADARI, cara membersihkan organ genetalia yang benar dan tata cara persiapan pelaksanaaan pemeriksaan tes IVA. Metode pengabdian pada masyarakat ini melalui penyuluhan dengan tujuan untuk memberikan pengetahuan agar berperilaku benar yang akurat mengenai kesehatan reproduksi masing-masing wanita pengajian Aisyiyah Turisari, Desa Palur Kulon, Kecamatan Mojolaban, Kabupaten Sukoharjo. Setelah kegiatan penyuluhan selesai, maka diberikan kuesioner untuk diisi oleh semua peserta. Tempat pelaksanaan kegiatan dilakukan di Masjid Baiturrahmah Turisari, Desa Palur Kulon, Kecamatan Mojolaban pada hari Jum'at, 21 Desember 2018. Kegiatan ini diikuti oleh 105 wanita yang tergabung dalam kegiatan pengajian rutin ibu-ibu yang biasanya diadakan sebulan sebanyak 2 kali.

Langkah-langkah pelaksanaan kegiatan pengabdian ini dimulai dari registrasi absensi seluruh peserta saat peserta memasuki lokasi penyuluhan. Setelah absensi, dilakukan apersepsi lisan pada peserta mengenai cara membersihkan organ genetalia dan cara memeriksa payudara sendiri. Selanjutnya, peserta diberi edukasi mengenai pengetahuan kesehatan reproduksi wanita bersama tim edukasi dari Program Studi D3 Kebidanan Sekolah Vokasi, Universitas Sebelas Maret dan juga tim dokter dari Rumah Sakit Dr. Moewardi Surakarta. Setelah kegiatan penyuluhan edukasi diberikan, maka di akhir sesi peserta diminta mengisi secara langsung saat kegiatan inti selesai berupa kuesioner sebanyak 10 butir pertanyaan. Salah satu keberhasilan kegiatan pengabdian masyarakat berupa edukasi ini yaitu peserta dapat mengisi kuesioner dengan benar minimal $80 \%$ pertanyaan, peserta dapat mempraktikkan cara pemeriksaan payudara sendiri dan peserta mau melakukan pemeriksaan tes IVA di Puskesmas setempat. Harapan setelah edukasi dilaksanakan dan kuesioner dikerjakan yaitu para wanita mampu menjawab pertanyaan dengan benar rentang nilai 80-100 dalam kategori pengetahuan baik, rentang nilai 60-79 untuk pengetahuan sedang, rentang nilai 40-59 untuk pengetahuan buruk dan nilai 20-39 untuk pengetahuan sangat buruk.

\section{HASIL DAN PEMBAHASAN}

Hasil kegiatan pengabdian pada masyarakat mengenai edukasi memberi pengetahuan agar berperilaku benar yang akurat mengenai kesehatan reproduksi masing-masing wanita pada kelompok ibu-ibu jama'ah pengajian Aisyiyah Turisari dihadiri oleh 105 peserta wanita yang diberi edukasi. Hasil dari 105 peserta wanita dibagi menjadi 50 wanita di usia produktif yang terbagi menjadi 40 wanita usia reproduksi pada rentang usia 25-35 tahun, 4 orang usia remaja awal di usia 12-16 tahun, 6 orang usia remaja akhir di usia 17-25 tahun, serta 55 wanita berusia lanjut usia. Jumlah wanita yang hadir pada kegiatan edukasi berdasarkan kelompok usia dapat dilihat pada Tabel 1.

Tabel 1. Jumlah wanita yang hadir pada kegiatan edukasi berdasarkan kelompok usia

\begin{tabular}{lcc}
\hline \multicolumn{1}{c}{ Usia wanita } & Jumlah & Persentase (\%) \\
\hline Reproduksi & 40 & 38,10 \\
Remaja awal & 4 & 3,81 \\
Remaja akhir & 6 & 5,71 \\
Lanjut usia & 55 & 52,30 \\
\hline Total & 105 & 100,00 \\
\hline
\end{tabular}

Berdasarkan Tabel 2 yang menyajikan data hasil evaluasi menggunakan kuesioner setelah kegiatan edukasi dilaksanakan, 60 orang wanita mempunyai pengetahuan baik, yaitu mampu menjawab pertanyaan dengan benar rentang nilai $80-100,25$ orang berpengetahuan sedang ditandai dengan nilai 60-79 dan 15 wanita mempunyai pengetahuan buruk dengan nilai 40 59 , serta 5 wanita berusia di atas 70 tahun tidak bersedia mengisi kuesioner karena usia lanjut 
sehingga tidak ada peserta dengan nilai 20-39 untuk pengetahuan sangat buruk.

Tabel 2. Jumlah responden berdasarkan kategori pengetahuan hasil pengisian kuesioner

\begin{tabular}{lc}
\hline \multicolumn{1}{c}{ Hasil kuesioner } & Jumlah \\
\hline Pengetahuan baik & 60 \\
Pengetahuan sedang & 25 \\
Pengetahuan buruk & 15 \\
Pengetahuan sangat buruk & 0 \\
Tidak mengisi & 5 \\
\hline Total & 105 \\
\hline
\end{tabular}

Kegiatan pengabdian yang dihadiri oleh ibu-ibu pengajian Aisyiyah Turisari sangat bermanfaat karena dapat menambah pengetahuan tentang cara menjaga kesehatan alat reproduksi wanita serta pencegahan dini terjadinya kanker payudara wanita (Gambar 1). Jumlah penduduk wanita di kawasan Palur Kulon ini yang termasuk Kecamatan Mojolaban sekitar 452.524 jiwa, 126.024 jiwa terdiri dari wanita berumur 25-34 tahun dalam rentang usia reproduksi sehat yang sangat perlu diberikan pendidikan kesehatan ataupun edukasi mengenai pentingnya menjaga kesehatan reproduksi dalam sepanjang kehidupan wanita tersebut dimulai saat anakanak, remaja, wanita usia subur, pasangan usia subur sampai dengan masa klimakterium (Pemkab Sukoharjo, 2018).

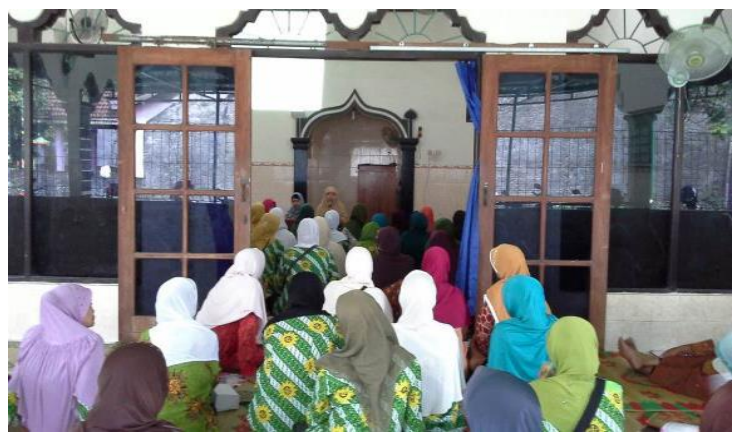

a.

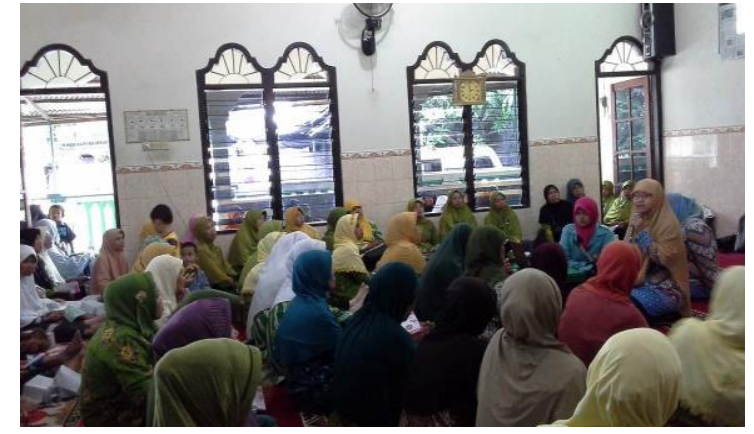

b.

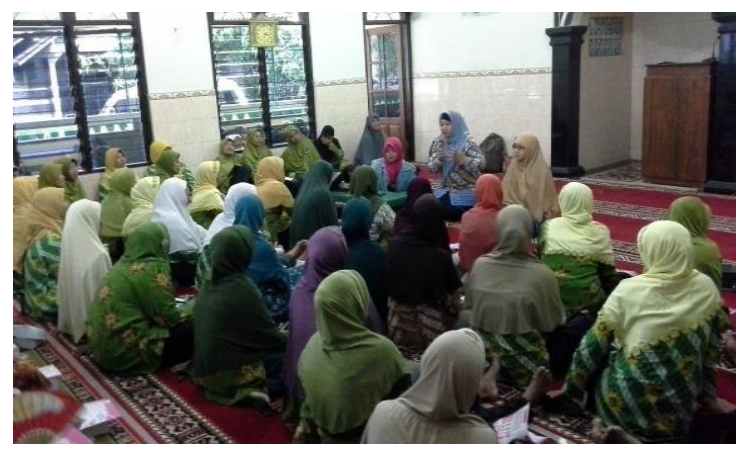

C.

Gambar 1. Suasana saat edukasi kesehatan reproduksi wanita pada pengajian Aisyiyah Turisari (a), saat tanya jawab dengan pemateri pertama (b) dan kedua (c)

Data mengenai kesehatan reproduksi wanita di Sukoharjo menyebutkan bahwa sasaran pada pemeriksaan SADANIS dan pemeriksaan tes IVA pada wanita usia 30-50 tahun sebanyak 139.330. Capaian pemeriksaan leher rahim dan payudara 3.675 orang $(2,64 \%)$. Data mengenai tes IVA positif sebanyak 890 orang $(24,22 \%)$. Kasus dengan tumor atau benjolan 38 orang $(1,03 \%)$. Capaian pelayanan IVA masih sangat rendah karena masih rendahnya kesadaran untuk melaksanakan deteksi dini kanker leher rahim maupun kanker payudara.

Sekitar $90 \%$ dari semua lesi payudara dideteksi oleh individu sendiri. Kanker payudara merupakan penyebab utama kematian akibat kanker pada wanita. Kanker serviks di Indonesia merupakan kasus terbanyak dan hampir 70\%-nya ditemukan dalam kondisi stadium lanjut. Hal ini disebabkan karena masih rendahnya pelaksanaan skrining yaitu hanya 5\%. Pelaksanaan skrining 
yang ideal adalah $80 \%$. Hal inilah penyebab jumlah kasus baru kanker serviks mencapai 40-45 per hari dan jumlah kematian akibat kanker serviks 20-25 per hari (Samadi, 2011). Tenaga kesehatan memiliki peran penting dalam menyelenggarakan skrining dan penyuluhan kanker payudara dan tes IVA. Apabila tumor dapat dideteksi lebih dini dalam kondisi masih terlokalisasi, angka kelangsungan hidup mencapai $100 \%$ (Bobak et al., 2005).

Kanker payudara menempati peringkat kedua kematian akibat kanker terbanyak di Indonesia dengan 22.000 kematian pada tahun 2018. Angka kematian yang tinggi tersebut diperparah dengan fakta bahwa $80 \%$ kasus kanker payudara di Indonesia terdeteksi saat sudah berada pada stadium lanjut, sehingga meningkatkan angka morbiditas dan mortalitas (Rahayu et al., 2020). Cara deteksi yang paling sederhana dan mudah, murah, ialah melalui SADARI.

Hasil penelitian dari Ermiati dan Widiasih (2018) mengenai upaya promosi dan prevensi kesehatan reproduksi wanita oleh petugas kesehatan menunjukkan bahwa upaya promosi dan prevensi tentang pemeriksaan payudara sendiri dan vagina sendiri masing-masing 18 responden (49\%) dan sebagian besar responden menjelaskan tentang pap smear yaitu 22 responden (60\%). Upaya promosi dan prevensi terhadap deteksi dini kurang menjadi perhatian bagi tenaga kesehatan di ruang kebidanan. Deteksi dini dengan melakukan SADARI, tes IVA merupakan salah satu cara yang paling mudah dilakukan untuk mendeteksi awal adanya kelainan pada payudara dan vagina (Ermiati dan Widiasih, 2018).

Berdasarkan data dari Kementerian Kesehatan Republik Indonesia (Kemenkes) tahun 2015 dari Profil Kesehatan Indonesia, 2015 menunjukkan bahwa dari 100.000 kelahiran hidup di Indonesia, 305 diantaranya berakhir dengan kematian sang ibu. Rencana Pembangunan Jangka Menengah Nasional (RPJMN) 2014-2019, pemerintah menargetkan penurunan AKI dari 205/100.000 kelahiran menjadi 276/100.000 kelahiran hidup (Arief, 2018). Tingginya AKI dipengaruhi pula saat ibu belum menikah, yaitu saat remaja, maupun saat setelah menikah dalam merawat organ reproduksinya.

Pemahaman kesehatan reproduksi tersebut termasuk pula adanya hak-hak setiap orang untuk memperoleh pelayanan kesehatan reproduksi yang aman, efektif dan terjangkau. Pelayanan kesehatan sistem reproduksi adalah pelayanan kesehatan yang ditujukan kepada suatu rangkaian organ, interaksi organ dan zat dalam tubuh manusia yang dipergunakan untuk berkembang biak. Pengaturan kesehatan reproduksi bertujuan untuk menjamin pemenuhan hak kesehatan reproduksi setiap orang yang diperoleh melalui pelayanan kesehatan yang bermutu, aman dan dapat dipertanggungjawabkan dan menjamin kesehatan ibu dalam usia reproduksi agar mampu melahirkan generasi yang sehat dan berkualitas serta mengurangi AKI (PP No. 61 tahun 2014).

Definisi kesehatan reproduksi telah diatur dalam Undang-Undang RI No. 36 tahun 2009 mengenai kesehatan, yaitu keadaan sehat secara fisik, mental dan sosial secara utuh, tidak sematamata bebas dari penyakit atau kecacatan yang berkaitan dengan sistem, fungsi dan proses reproduksi pada laki-laki dan perempuan (Pasal 71 Undang-Undang No. 36 tahun 2009). Ruang lingkup pelayanan kesehatan repoduksi menurut ICPD tahun 1994 di Kairo terdiri dari kesehatan ibu dan anak, keluarga berencana, pencegahan dan penanganan infeksi menular seksual termasuk Human Immunodeficiency Virus (HIV) dan Acquired Immuno Deficiency Syndrome (AIDS), kesehatan reproduksi remaja, pencegahan dan penanganan komplikasi aborsi, pencegahan dan penanganan infertilitas, kesehatan reproduksi usia lanjut, deteksi dini kanker saluran reproduksi serta kesehatan reproduksi lainnya seperti kekerasan seksual, sunat perempuan dan sebagainya (Pasal 71 Undang-Undang Nomor 36 Tahun 2009).

Kesehatan reproduksi yang ada dalam konteks pembangunan masyarakat Indonesia mencakup 5 (lima) komponen/program terkait, yaitu program Kesehatan Ibu dan Anak (KIA), program Keluarga Berencana (KB), program Kesehatan Reproduksi Remaja (KRR), program Pencegahan dan Penanggulangan Penyakit Menular Seksual (PMS) termasuk HIV/AIDS dan program Kesehatan Reproduksi pada Usia Lanjut. Pelaksanaan kesehatan reproduksi dilaksanakan dengan menggunakan pendekatan siklus hidup agar diperoleh sasaran yang pasti dan pelayanan yang jelas berdasarkan kepentingan sasaran/ klien dengan memperhatikan hak reproduksi. Kesehatan reproduksi memiliki tiga komponen yaitu kemampuan prokreasi, mengatur dan menjaga tingkat kesuburan dan menikmati kehidupan seksual secara bertanggung jawab. Prioritas dari pelayanan kesehatan reproduksi pada konteks saat ini masih dalam hal KIA, KB, 
KRR dan PKMS (Direktorat Kesehatan Keluarga, 2017).

Kegiatan edukasi kesehatan reproduksi wanita pada jama'ah pengajian Aisyiyah ini merupakan salah satu alternatif pelayanan kesehatan reproduksi terjangkau, baik dari sisi ekonomis maupun dari sisi kepraktisan efisiensi tenaga dan waktu. Para wanita diharapkan bisa praktik dan rajin melakukan SADARI minimal sebulan satu kali, saat menjelang atau setelah menstruasi. Selain itu, diharapkan agar bisa dan mau melakukan cara membersihkan genetalia yang benar, tentang cara arah bercebok, cairan pembersih yang tidak boleh digunakan setiap hari tanpa resep atau arahan dari dokter. Setelah mereka mau menerapkan hal-hal tersebut, maka para wanita yang telah menikah diharapkan tidak malu dan mau untuk melakukan pemeriksaan tes IVA di Puskesmas dengan biaya sangat terjangkau. Salah satu tujuan dari tes IVA ini adalah sebagai deteksi awal ketidaknormalan organ reproduksi bagian bawah, yang apabila tidak segera mendapat penanganan secara tepat, bisa berakibat keganasan atau kanker. Kanker ini selain merusak organ reproduksi, bisa menjalar ke organ vital dari tubuh, yang sangat mungkin membahayakan keselamatan seorang wanita. Setelah kegiatan ini terselenggara, dari pihak pengurus pengajian akan melakukan follow up lebih lanjut ke Kader Kesehatan Puskesmas, apakah para ibu akhirnya mau melakukan pemeriksaan tes IVA di Puskesmas.

\section{KESIMPULAN}

Berdasarkan hasil kegiatan dapat disimpulkan bahwa masih terdapat wanita yang mempunyai pengetahuan sedang (25 orang) dan pengetahuan buruk (15 orang) dari total 105 wanita. Meskipun sudah 60 orang mempunyai pengetahuan yang benar tentang menjaga kesehatan reproduksinya, tetapi kegiatan edukasi ini sebaiknya dilakukan secara periodik karena masih terdapat beberapa wanita yang belum paham berperilaku hidup sehat, terutama dalam menjaga kondisi kesehatan reproduksinya, mulai dari anak-anak, remaja, dewasa, istri maupun ibu sampai kondisi wanita tersebut memasuki masa menopause. Para wanita dimulai dari masa remajanya diharapkan bisa mempraktikkan SADARI secara benar minimal satu bulan satu kali, bisa praktik setiap hari tentang cara merawat organ genetalia melalui cara cebok yang benar hingga remaja tersebut menjadi dewasa dan menikah, bersedia melakukan pemeriksaan tes IVA di Puskesmas untuk mendeteksi ketidaknormalan di organ genetalianya.

\section{UCAPAN TERIMA KASIH}

Penulis menyampaikan terima kasih kepada pengurus pengajian Aisyiyah Turisari, Desa Palur Kulon, Kecamatan Mojolaban, Kabupaten Sukoharjo yang telah memberikan kesempatan kepada tim pengabdian untuk melakukan edukasi. Selain hal tersebut, kami juga mengucapkan terima kasih kepada semua tim pelaksana kegiatan pengabdian yang telah bekerjasama dengan baik sehingga ibu-ibu jama'ah pengajian Aisyiyah Turisari menjadi lebih mengerti mengenai edukasi pentingnya menjaga kesehatan reproduksi wanita. Ucapan terima kasih terkhusus kepada tim jurnal P4GKM (Pusat Penelitian dan Pengembangan Pangan, Gizi dan Kesehatan Masyarakat) LPPM Universitas Sebelas Maret yang selalu memberi motivasi dorongan untuk menyusun artikel ini sampai dengan selesai.

\section{DAFTAR PUSTAKA}

Arief. (2018). Kematian Ibu dan Upaya-Upaya Penanggulangannya. Jakarta. Tersedia dari https://pkbi.or.id/kematian-ibu-dan-upayaupaya-penanggulangannya/

Bobak, I. M., Lowdermilk, D. L., \& Jensen, M. D. (2005). Maternity nursing. (4th ed). (Wijayarini, M.A., \& Anugrah, P.I, Penerjemah). California: Mosby. (Sumber asli diterbitkan, 1995).

Direktorat Kesehatan Keluarga Kemenkes RI. (2017). Upaya pemenuhan hak kesehatan reproduksi melalui Pelayanan Kesehatan Reproduksi Terpadu (PKRT). Jakarta. Tersedia dari http://kesga.kemkes.go.id/beritalengkap.php?id=35-Upaya\%20Pemenuhan\% 20Hak\%20Kesehatan\%20Reproduksi\%20\%2 0Melalui\%20Pelayanan\%20Kesehatan\%20Re produksi\%20Terpadu\%20(PKRT)

Ermiati, \& Widiasih, R. (2018). Upaya promosi dan prevensi kesehatan reproduksi wanita oleh petugas kesehatan. Idea Nursing Journal, 9(1), 47-56. Tersedia dari http://jurnal.unsyiah.ac.id /INJ/article/view/10335 
Rahayu, R. F., Ropitasari, Prabata, A., \& Maharina, L. (2020). Karakteristik hasil ultrasonografi payudara pada program deteksi dini kanker. AgriHealth: Journal of Agri-food, Nutrition and Public Health, l(1), 1-6, 2020. http://dx.doi.org/10.20961/ agrihealth.v1i1.41124

Pemkab Sukoharjo. (2018). Data Kependudukan Sukoharjo. Tersedia dari http://sukoharjo kab.go.id/laporan_kependudukan/

Peraturan Pemerintah RI UU Nomor 36 tahun 2009 Pasal 71 tentang Kesehatan Reproduksi.
Tersedia dari https://infeksiemerging.kemkes. go.id/download/UU_36_2009_Kesehatan.pdf

Peraturan Pemerintah RI UU Nomor 61 tahun 2014 tentang Kesehatan Reproduksi. Tersedia dari http://kesga.kemkes.go.id/images/pedom an/PP\%20No.\%2061\%20Th\%202014\%20ttg $\% 20$ Kesehatan\%20Reproduksi.pdf

Samadi, H. P. (2011). Yes, I know everyting about Kanker Serviks: Mengenali, Mencegahnya dan Bagaimana anda Menjalani Pengobatannya. Solo: Tiga Serangkai Pustaka Mandiri 